\title{
RANCANG BANGUN SISTEM INFORMASI SEKOLAH TERPADU DI SDN PACARKELING 5 SURABAYA
}

\author{
Triuli Novianti \\ Universitas Muhammadiyah Surabaya \\ Surabaya, Indonesia \\ triuli81@yahoo.com
}

\begin{abstract}
Abstrak
Pemanfaatan teknologi komputer khususnya di sekolah dapat menggunakan kemajuan komputer dalam pengelolaan data secara online. Dengan sistem ini administrator dapat menyimpan dan mengunduh data yang telah tersimpan dan web bisa dibuka dimana saja dan kapan saja. Penelitian ini membahas tentang rancang bangun sistem informasi sekolah terpadu di SDN Pacarkeling 5 Surabaya meliputi : pendataan siswa, nilai dan perkembangan siswa serta penyampaian berbagai info tentang sekolah. Tujuan dari perancangan dan pembuatan sistem informasi sekolah terpadu di SDN Pacarkeling 5 Surabaya berbasis website menggunakan PHP dan MySql ini antara lain : memudahkan pendataan siswa, mempermudah penyampaian informasi kepada orang tua siswa dan masyarakat serta sebagai pusat informasi baik untuk orang tua dan masyarakat. Sistem informasi sekolah terpadu di SDN Pacarkeling $\mathrm{V}$ berbasis web ini : memudahkan admin untuk pendataan siswa, mempermudah sekolah untuk menyampaikan informasi-informasi tentang sekolah kepada orang tua dan masyarakat dan mempermudah orang tua untuk mengetahui perkembangan putra-putrinya.
\end{abstract}

Kata kunci : sistem informasi sekolah, PHP, MySql 


\begin{abstract}
The use of computer technology, especially in the school can use the computer advances in the management of online data. By using this system administrator can store and download the data that has been stored and the web can be opened anywhere and anytime. This study discusses the design of integrated information systems school in SDN Pacarkeling 5 Surabaya include: student data collection, the value and the development of students as well as the delivery of a wide range of information about the school. The purpose of the design and manufacture of integrated information systems school in Surabaya SDN Pacarkeling 5 based websites using PHP and MySQL, among others: facilitate student data collection, facilitate the delivery of information to parents and the community as well as an information center for both parents and the community. School information system integrated in a web-based SDN Pacarkeling $V$ is: easy admin for student data collection, enabling the school to convey information about the school to parents and the community and facilitate parents to know the progress of their children.
\end{abstract}

Keywords: school information system, PHP, MySql 


\section{PENDAHULUAN}

Perkembangan ilmu pengetahuan disegala bidang dalam era gobalisasi saat ini begitu pesat. Terutama dibidang IT yang semakin maju seiring dengan kebutuhan pemakai (user) untuk memperoleh suatu karya atau inovasi maksimal serta memperoleh kemudahan dalam segala aktifitas. Sistem ini mempunyai peranan yang sangat penting dalam menyimpan data, karena system yang manual akan sangat merepotkan bagian administrator, terutama bila terjadi kehilangan data. Aplikasi web bisa digunakan untuk menyimpan, mencari data, memberi informasi tentang sekolah. Dengan demikian para admin, misalnya admin di sekolah dapat menyimpan dan mencari data sekolah secara cepat, misalnya data siswa, karyawan dan galeri.

Pemanfaatan teknologi komputer khususnya di sekolah dapat menggunakan kemajuan komputer dalam pengelolaan data secara online. Dengan sistem ini administrator dapat menyimpan dan mengunduh data yang telah tersimpan dan web bisa dibuka dimana saja dan kapan saja.

Makalah ini membahas tentang rancang bangun sistem informasi sekolah terpadu di SDN Pacarkeling 5 Surabaya meliputi : pendataan siswa, nilai dan perkembangan siswa serta penyampaian berbagai info tentang sekolah.

Tujuan dari perancangan dan pembuatan sistem informasi sekolah terpadu di SDN Pacarkeling 5 Surabaya berbasis website menggunakan PHP dan MySql ini antara lain : memudahkan pendataan siswa, mempermudah penyampaian informasi kepada orang tua siswa dan masyarakat serta sebagai pusat informasi baik untuk orang tua dan masyarakat.
Adapun batasan permasalahan yang akan dibahas pada makalah ini sebagai berikut : bahasa pemrograman yang di gunakan adalah PHP dan MySQL sebagai databasenya, data yang ditampilkan tidak terkait dengan inventaris barang, pengunjung web hanya bisa melihat data/informasi, yang bisa menginputkan data adalah admin/user sedangkan guru hanya bisa menginputkan nilai siswa dan kepala sekolah hanya bisa melihat data.

Metode penelitian pada makalah ini adalah sebagai berikut: pertama, melakukan identifikasi dengan mengetahui langsung kondisi informasi sekolah. Kedua, metode observasi dengan melakukan pengamatan seputar informasi sekolah. Ketiga, melakukan studi literatur dan konsultasi, mengumpulkan data - data yang berhubungan dengan tema makalah. Keempat, pembuatan desain dan coding dengan merancang desain yang akan di gunakanan serta menggabungkan dengan script atau coding yang sesuai dengan ruang lingkup yang ada. Kelima, melakukan pengujian program, dengan menguji hasil perancangan apakah bisa di jalankan dengan baik tanpa ada masalah.

Sistematika makalah ini secara keseluruhan tercakup dalam lima bab sebagai berikut : bab pertama pendahuluan, kedua landasan teori, ketiga perancangan dan implementasi sistem, keempat pengujian sistem dan terakhir penutup, kesimpulan dan saran.

\section{METODE PENELITIAN}

Konsep sistem informasi sekolah terpadu secara on-line adalah menggunakan koneksi internet sebagai bagian utama. Oleh karena itu dibutuhkan ketersediaan jaringan internet, komputer 
atau laptop serta tenaga admin. Sistem ini membutuhkan database sebagai penyimpanan data arsip sekolah. Dengan adanya database ini maka pengolahan data akan lebih cepat .

\section{Peralatan yang digunakan}

Pada dasarnya sistem informasi sekolah ini adalah aplikasi Client/Server yang menggunakan media internet. Untuk dapat berjalan dengan baik, aplikasi ini membutuhkan beberapa komponen utama, yaitu :

1. Server web sebagai server.

2. Browser web sebagaiclient.

3. Server database.

Hubungan antar komponen tersebut digambarkan sebagai berikut :

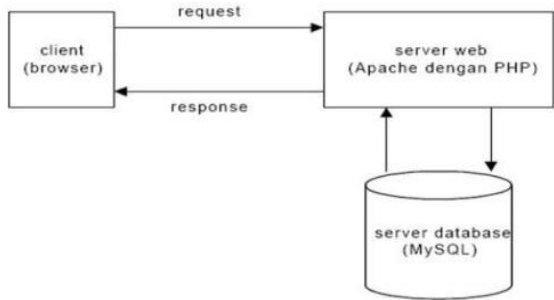

Gambar 1. Hubungan antar komponen aplikasi web

Adapun perangkat lunak yang di gunakan pada aplikasi ini adalah sebagai berikut :

1. Apache 2.2.17, sebuah server web berkemampuan tinggi.

2. Mozila firefox versi 12.0 sebagai client server.

3. MySQL 5.5.8, sebuah RDBMS (Relational Database Management System) multiuser berkemampuan tinggi yang dirancang untuk bekerja pada berbagai macam platform.

4. PHP 5.3.5 (VC6 X86 32bit) yang merupakan bagian dari server web.
5. phpMyAdmin 3.3.9 yang berfungsi sebagai perancang database.

6. xampp-win32-1.8.1-VC9

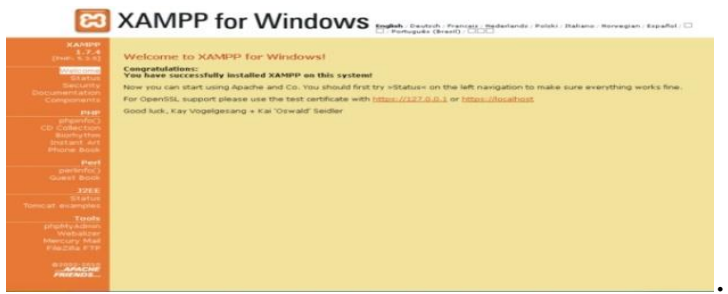

Gambar 2. Tampilan XAMMP

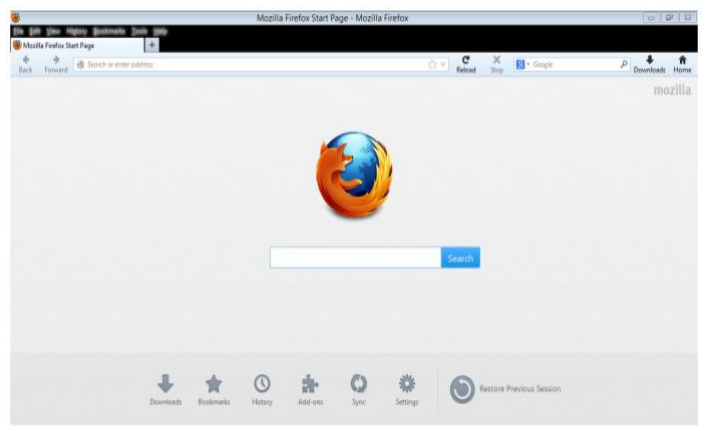

Gambar 3. Tampilan mozila firefox

\section{Sistem Flow}

Untuk lebih memperjelas proses kerja dari aplikasi yang dibuat pada setiap entiti diuraikanlah proses tersebut ke dalam bentuk Sistem Flow, sehingga dari sistem flow terlihat kerja dan ruang lingkup dari sistem yang dirancang serta elemen-elemen yang terlibat didalamnya, baik berupa perangkat lunak maupun perangkat keras dapat dilihat pada gambar berikut: 


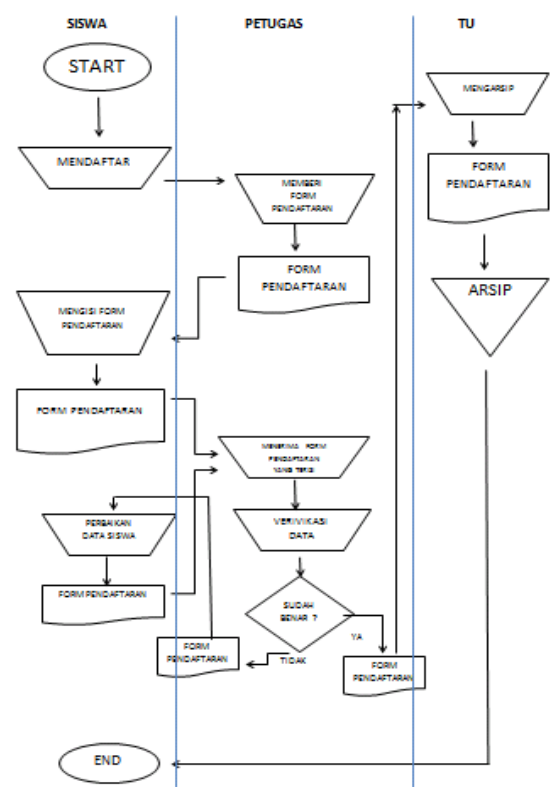

Gambar 4. Dock. Flow siswa

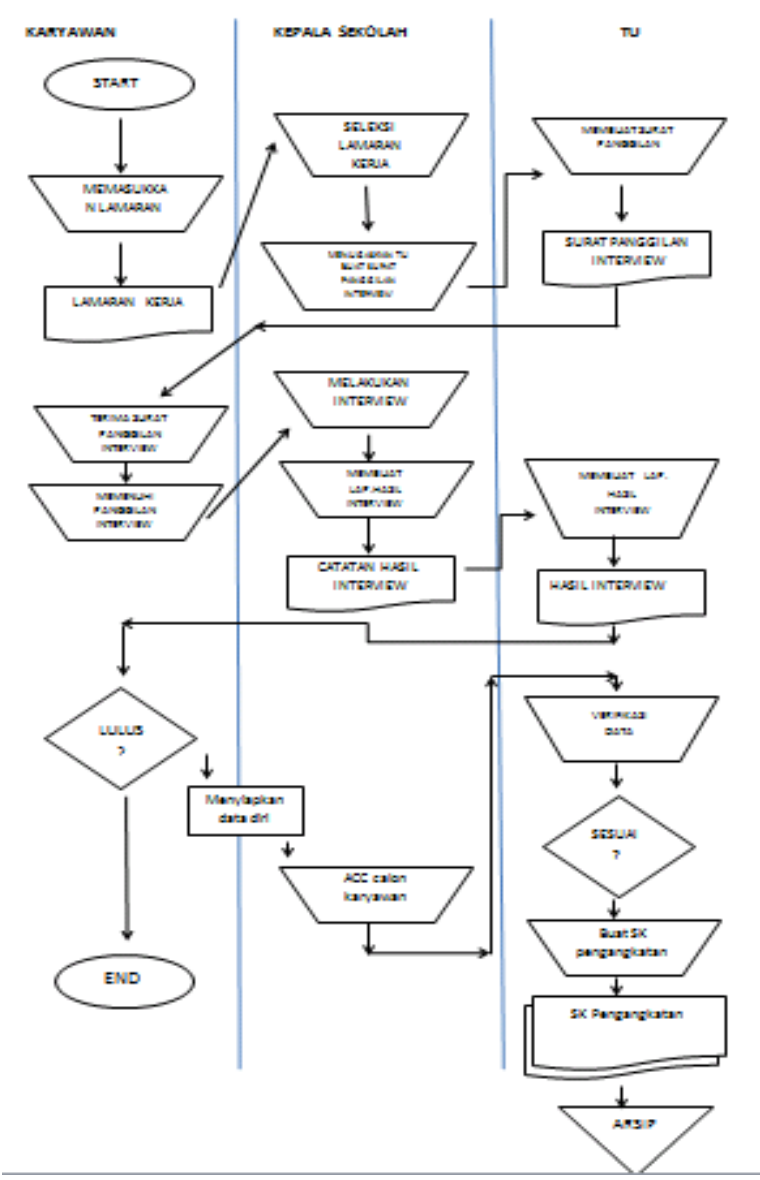

Gambar 5. Dock. Flow karyawan

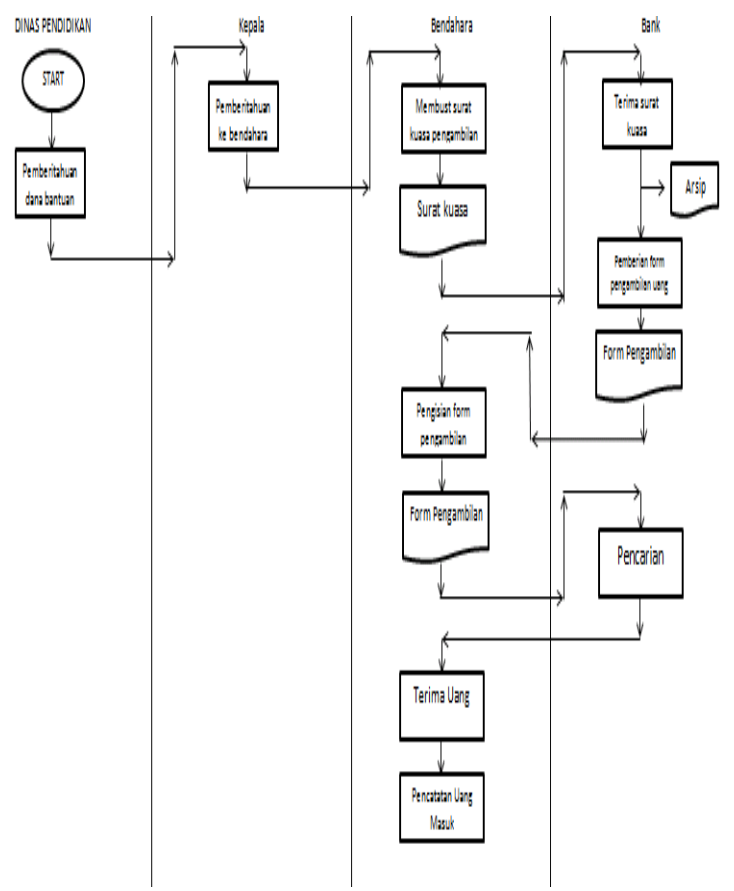

Gambar 6. Dock. Flow Uang Masuk

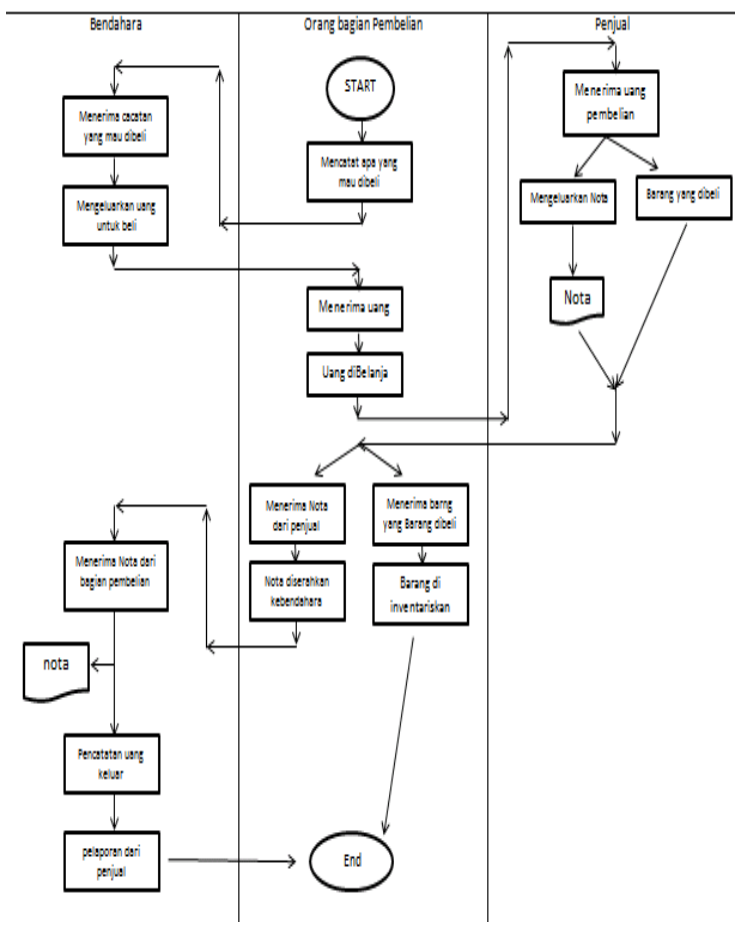

Gambar 7. Dock. FlowUang Keluar 


\section{Data Flow Diagram (DFD)}

Dengan mengacu pada context diagram maka untuk lebih memperjelas proses kerja dari aplikasi diuraikanlah proses tersebut ke dalam bentuk Data Flow Diagram (DFD), sehingga dari DFD terlihat kerja dan ruang lingkup dari sistem yang dirancang. Pada pembahasan DFD dibatasi hanya pada level 1 sesuai dengan gambar berikut:

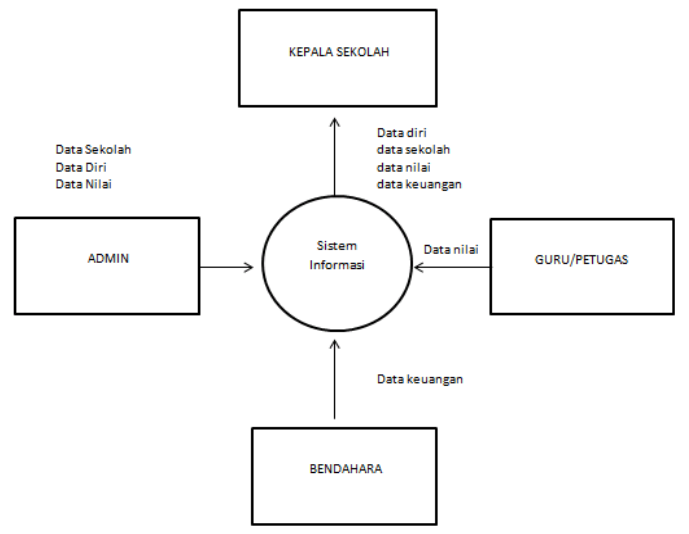

Gambar 8. Data Flow Diagram

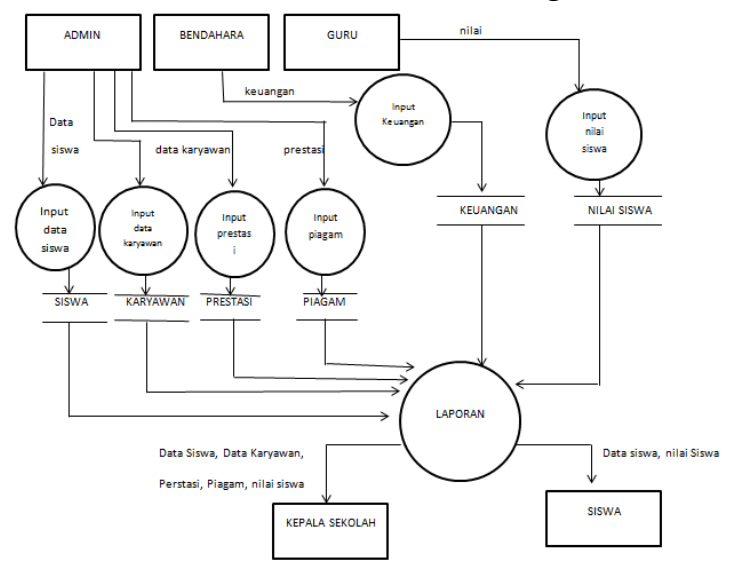

Gambar 9. Data Flow Diagram Level 1

\section{Struktur Database}

Sistem database dalam sistem Informasi Sekolah Terpadu berbasis web ini menggunakan MySQL versi 5.5.8 yang mana dalam perancangan databasenya menggunakan aplikasi php MyAdmin

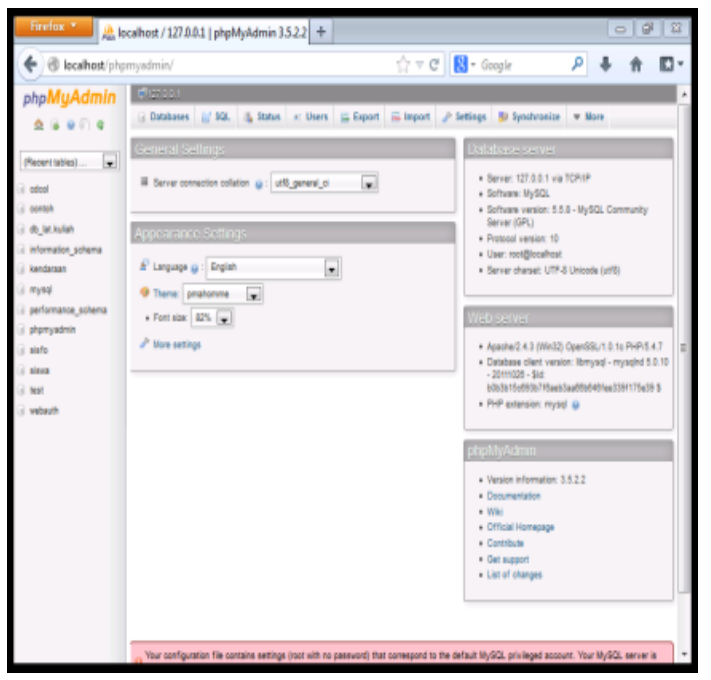

Gambar 10. Tampilan php MyAdmin

Database yang dibuat adalah database informasi sekolah yang terdiri dari delapan tabel yaitu : tabel_karyawan, tabel_kegiatan, tabel_mapel, tabel_nilai, tabel_piagam, tabel_prestasisiswa, tabel_siswa, tabel_uangkeluar, tabel_uangmasuk, user. Kedelapan tabel tersebut saling berelasi dengan keyword id dari masing - masing.

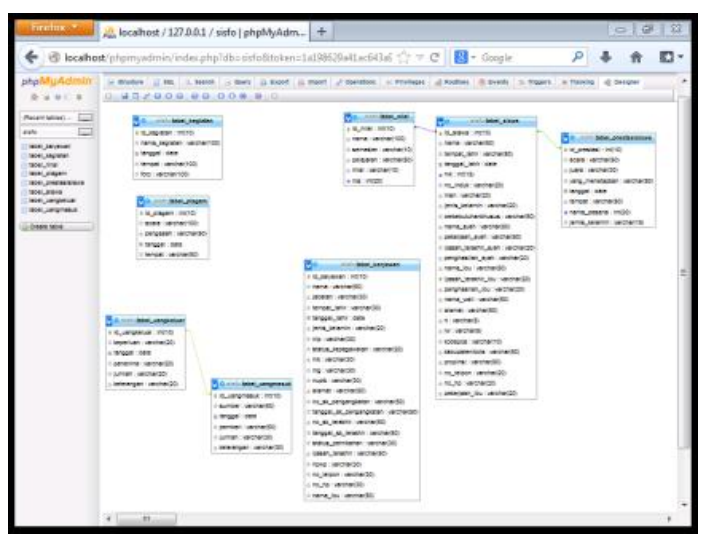

Gambar 11. Relasi database 


\section{Tabel Siswa}

Tabel ini mempunyai struktur sebagai berikut :

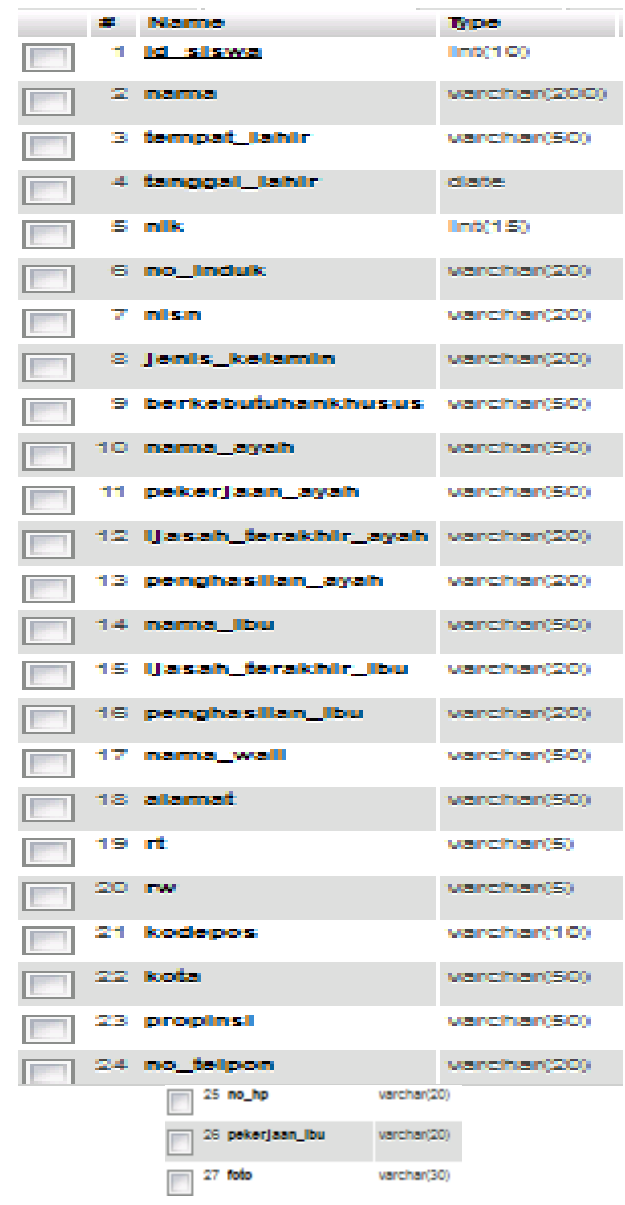

Tabel 1. Tabel siswa

Tabel ini berisi data calon pemilih yang sah dan mempunyai hak untuk membuka halaman awal web.

\section{Tabel Karyawan}

Mempunyai struktur sebagai berikut :

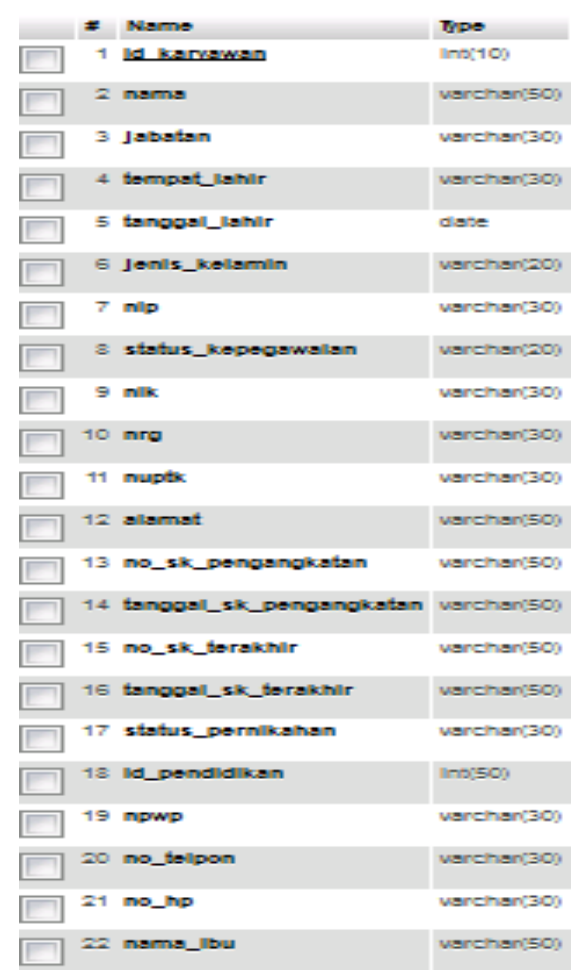

Tabel 2. Tabel Karyawan

Data karyawan tersimpan di dalam tabel karyawan dalam tabel ini adalah untuk mengetahui data yang bersangkutan.

\section{Tabel Nilai}

Mempunyai struktur sebagai berikut :

\begin{tabular}{|l|l|l|}
\hline \# & Name & Type \\
\hline$\square$ & 1 id nilai & int(10) \\
\hline$\square$ & 2 nama & varchar(100) \\
\hline$\square$ & 3 semester & int $(11)$ \\
\hline$\square$ & 4 pelajaran & varchar $(50)$ \\
\hline$\square$ & 5 nilai & varchar(10) \\
\hline$\square$ & 6 nis & varchar $(20)$ \\
\hline
\end{tabular}

Tabel 3. Tabel Nilai

Data Nilai tersimpan di dalam tabel nilaidalam tabel ini adalah untuk mengetahui data nilai yang bersangkutan. 


\section{Tabel Prestasi Siswa}

Mempunyai struktur sebagai berikut :

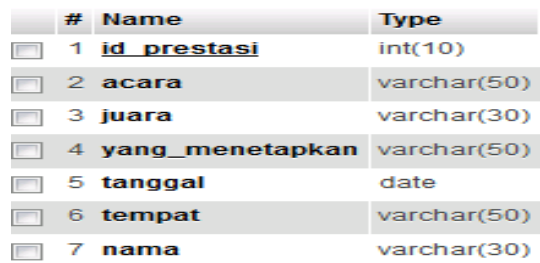

Tabel 4. Tabel Prestasi Siswa

Data prestosi tersimpan di dalam tabel prestasi dalam tabel ini adalah untuk mengetahui data prestasi yang bersangkutan.

\section{Tabel Piagam}

Mempunyai struktur sebagai berikut :

\begin{tabular}{|l|l|l|}
\hline \multicolumn{1}{|l|}{ \# } & Name & Type \\
$\square \quad 1$ & id piaqam & int(10) \\
\hline$\square \quad 2$ & acara & varchar(100) \\
\hline$\square \quad 3$ pengesah & varchar(50) \\
\hline$\square \quad 4$ tanggal & date \\
\hline$\square \quad 5$ tempat & varchar(50) \\
\hline$\square \quad 6$ foto & varchar(30) \\
\hline
\end{tabular}

Tabel 5. Tabel Piagam

Data piagam tersimpan di dalam tabel piagam dalam tabel ini adalah untuk mengetahui data piagam yang bersangkutan.

\section{Tabel Kegiatan}

Mempunyai struktur sebagai berikut :

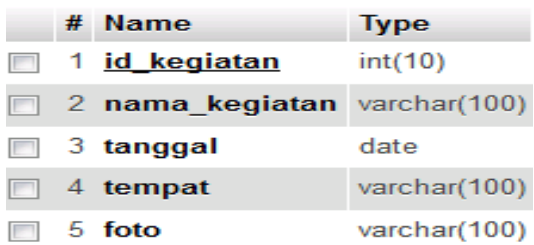

Tabel 6. Tabel Kegiatan

Data kegiatan tersimpan di dalam tabel kegiatan dalam tabel ini adalah untuk mengetahui kegiatan yang diadakan.

\section{Tabel Mapel}

Mempunyai struktur sebagai berikut :

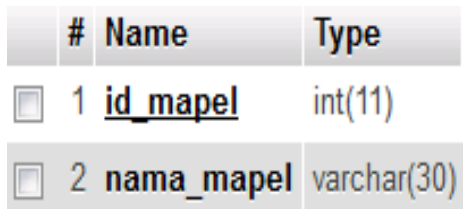

Tabel 7. Tabel mapel

Data mapel tersimpan di dalam tabel mapel dalam tabel ini adalah untuk mengetahui data mapel yang bersangkutan.

\section{Tabel Uang masuk}

Mempunyai struktur sebagai berikut :

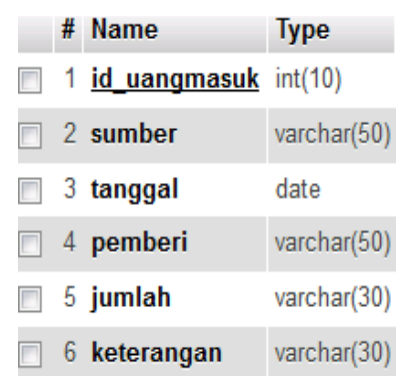

Tabel 8. Tabel Uang Masuk Data uang masuk tersimpan di dalam tabel uang masuk dalam tabel ini adalah untuk mengetahui data uang masuk yang diterima.

\section{Tabel Uang keluar}

Mempunyai struktur sebagai berikut :

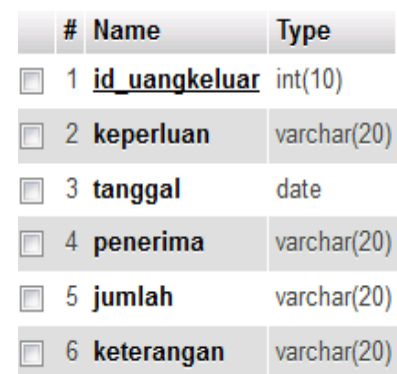

Tabel 9. Tabel Uang keluar 
Mempunyai struktur sebagai berikut :

\begin{tabular}{|c|c|c|c|}
\hline & \# & Name & Type \\
\hline 回 & 1 & id_uangkeluar & $\operatorname{int}(10)$ \\
\hline 口 & 2 & keperluan & varchar(20) \\
\hline$\square$ & 3 & tanggal & date \\
\hline$\square$ & 7 & penerima & $\operatorname{varchar}(20)$ \\
\hline 回 & 5 & jumlah & varchar(20) \\
\hline$\square$ & 0 & keterangan & varchar(20) \\
\hline
\end{tabular}

Tabel 10. Tabel User

Semua proses penambahan dan update pada aplikasi sistem Informasi Sekolah Terpadu SDN Pacarkeling V berbasis web ini dilakukan secara khusus oleh Administrator yang bertindak sebagai admin.

\section{HASIL PENELITIAN DAN PEMBAHASAN}

Secara umum, program aplikasi sistem Informasi Sekolah Terpadu SDN Pacarkeling V berbasis web ini terdiri dari delapan halaman utama, yaitu : halaman Home, halaman Karyawan, halaman Kegiatan, halaman Siswa, halaman Nilai Siswa, halaman Piagam, halaman Prestasi siswa, halaman Keuangan terdapat tiga sub halamanyaitu : halaman uang masuk, uang keluar, dan laporan. Pada halaman laporan terdapat tiga sub halaman : yaitu halaman laporan pertanggal, halaman laporan perbulan, halaman laporan pertahun.

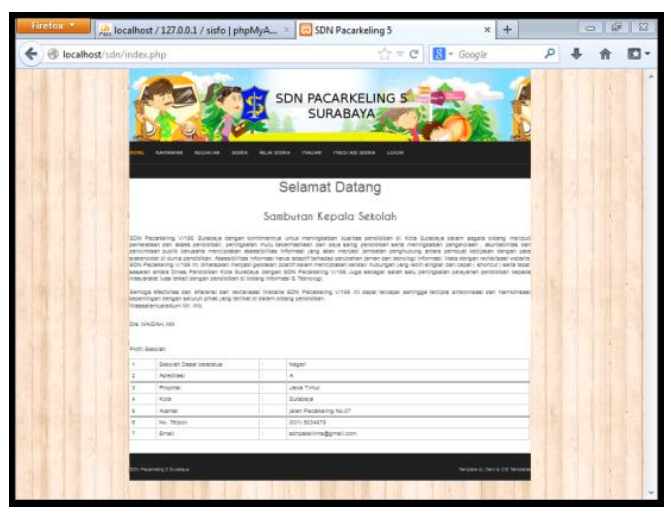

Gambar 12. Halaman awal

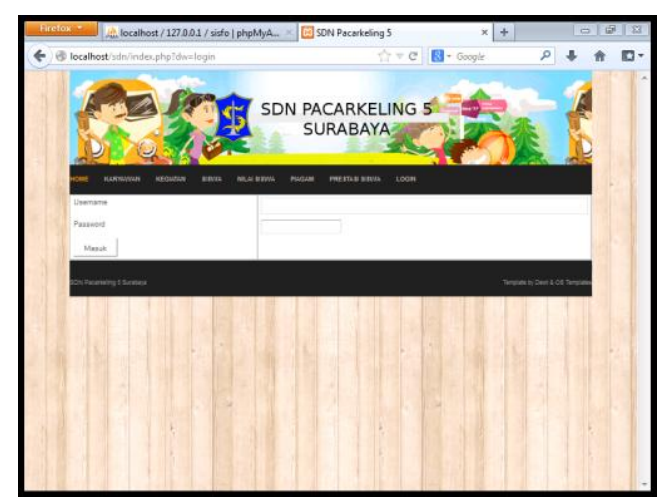

Gambar 13. Halaman login admin

\section{Alur Program}

Alur program dari sistem ini bisa kita lihat pada gambar yang ada di bawah ini :

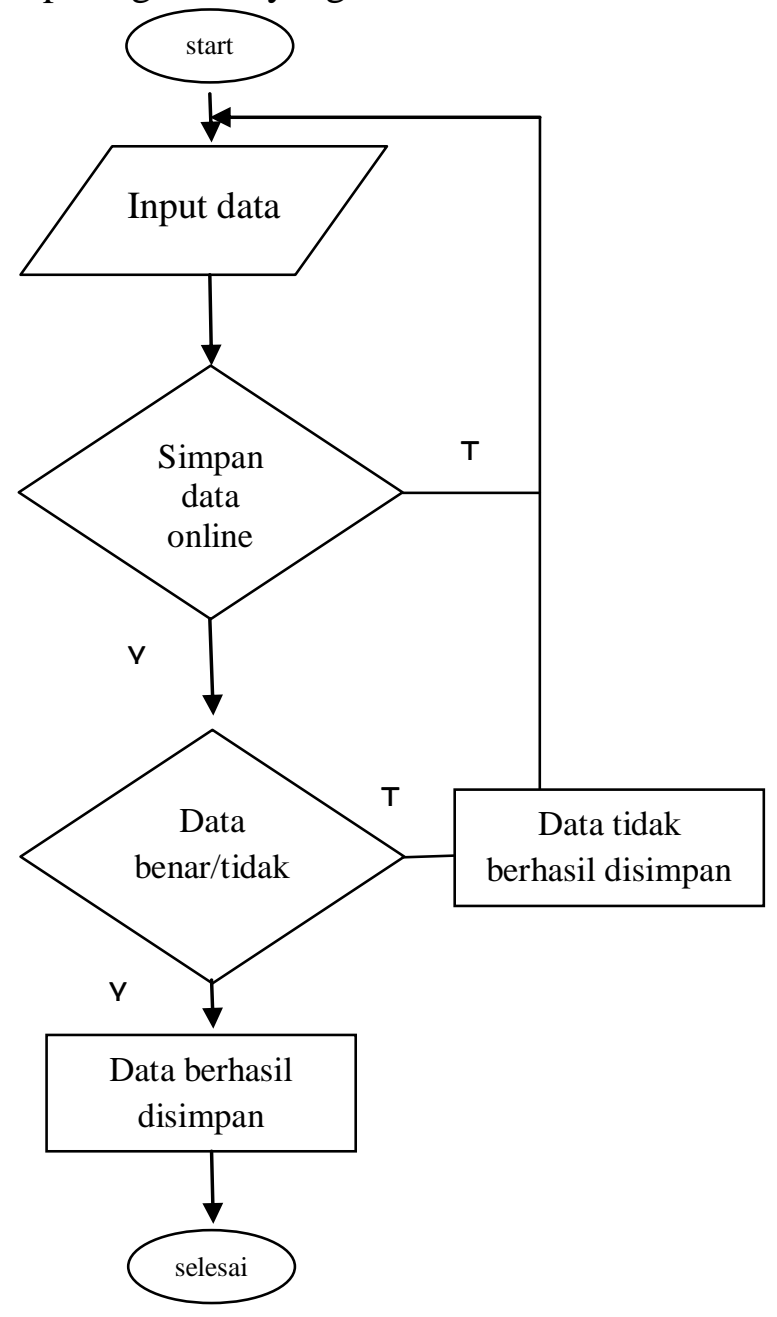

Gambar 14. Diagram alur sistem 
Pada gambar di atas bisa kita lihat, pengisisan data hanya bisa dilakukan oleh admin sekolah : data karyawan, data siswa, prestasi, piagam, dll.

1. Bila data benar, data akan langsung tersimpan.

2. Bila data tidak benar, data yang terisi akan hilang dan melakukan pengisian ulang hingga data berhasil tersimpan.

\section{Perancangan aplikasi antar muka}

Dalam membuat rancangan desain, penulis menggunakan bantuan web development, dalam hal ini adalah Adobe Dreamweaver CS4.

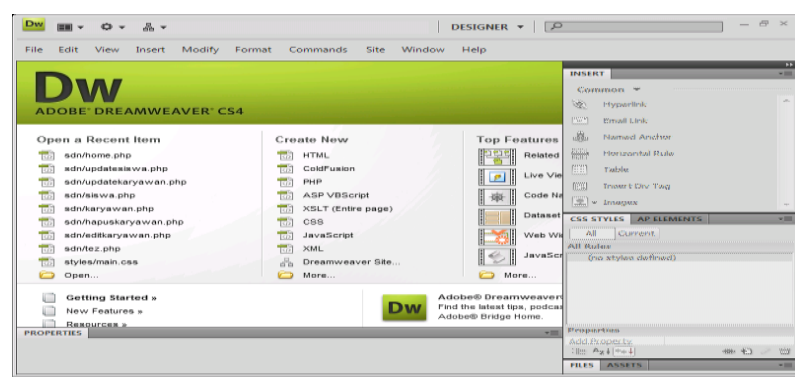

Gambar 15. Tampilan awal dreamweaver

\section{Penjelasan program}

Kode script aplikasi sistem Informasi

Sekolah Terpadu SDN Pacarkeling 5 berbasis web ini selengkapnya dapat menghubungi penulis. Sub bab ini akan menjelaskan satu per satu setiap bagian utama dari program tersebut.

\section{HalamanLogin}

Dalam halaman login,

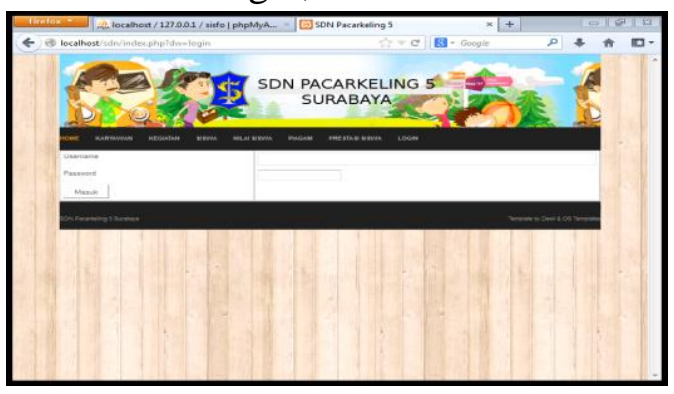

Gambar 16. Halamam login admin

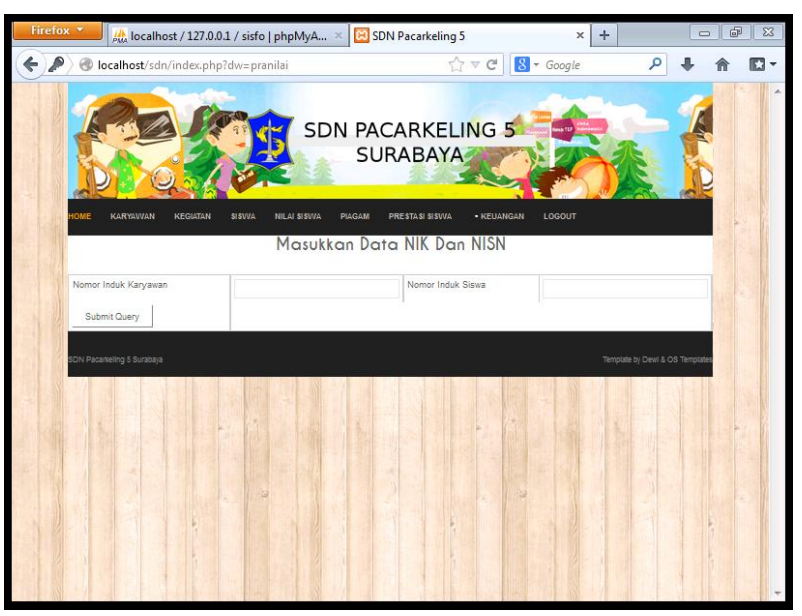

Gambar 17. Tampilan halaman login untuk mengisi nilai siswa

Setelah diisi dan meng'klik' tombol masuk, maka data yang diinputkan akan diperiksa ke database eksternal. Dalam halaman ini terdapat dua parameter login yaitu "admin" dan "nilai siswa". jika yang login level statusnya "admin", maka server akan mengarahkan ke halaman pengisian data. Sedangkan jika level statusnya "nilai siswa", maka server akan mengarahkan ke halaman pengisian nilai siswa. 


\section{Halaman Utama User}

Pada halaman utama ini akan ditampakkan sebuah tampilan pembuka.

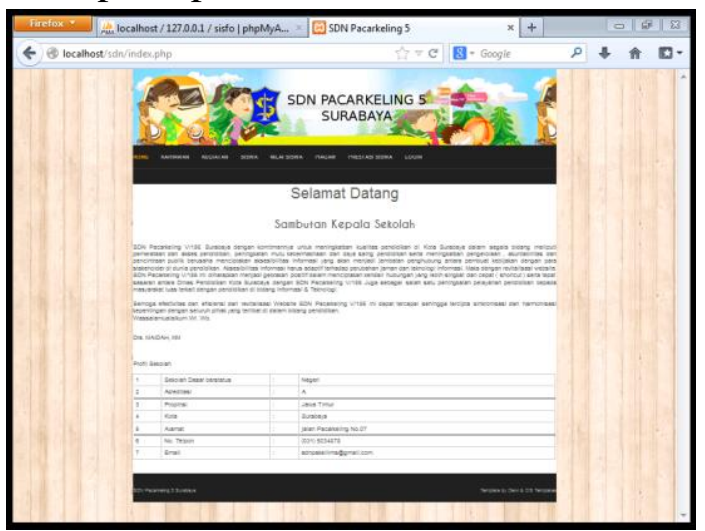

Gambar 18. Tampilan rancangan halaman utama

Adapun script dari halaman ini bisa di lihat di lampiran dengan nama user.php.

\section{Halaman Utama Admin}

Pada halaman utama ini akan ditampakkan sebuah tampilan pembuka.

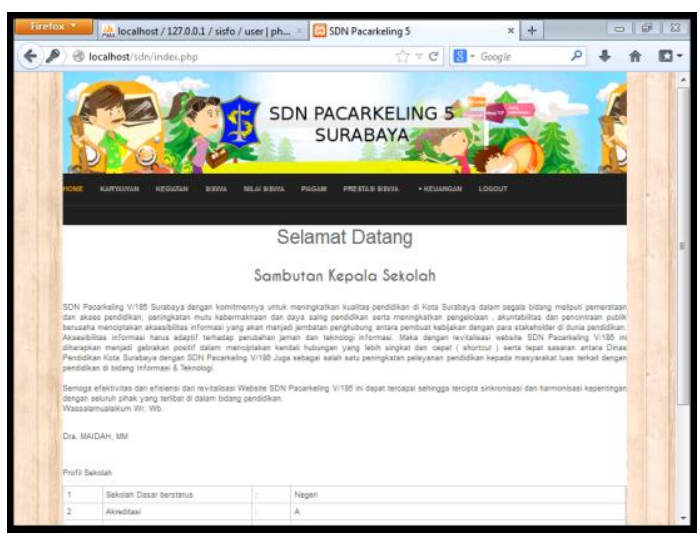

Gambar 19. Tampilan rancangan halaman utama

\section{Pengujian}

Setelah melalui proses desain dan pembuatan sistem, maka pada bab ini akan dilakukan pengujian sistem yang telah dinuat. Sistem yang dibuat menggunakan bahasa pemrograman PHP dan MySql.

\section{Hasil Pengujian}

Setelah merancang website Rancang Bangun Sistem Informasi Sekolah Terpadu di SDN Pacarkeling 5, penulis melakukan pengujian pada program yang telah di buat. Pengujian tersebut di mulai dari halaman home bagi pengunjung, dan halaman login bagi admin bertahap kehalaman user atau admin dan selanjutnya kehalaman berikutnya. Untuk lebih jelasnya, bias di lihat pada gambar - gambar yang ada di bawah ini :

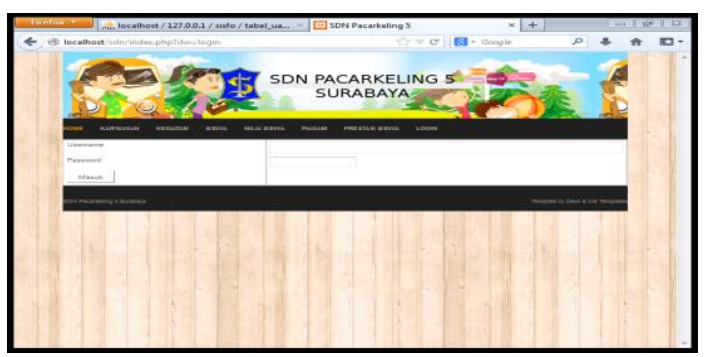

Gambar 20. Halaman login admin

Pada halaman ini admin di wajibkan mengisi text box yang ada dengan benar sesuai yang telahterdaftar pada database.

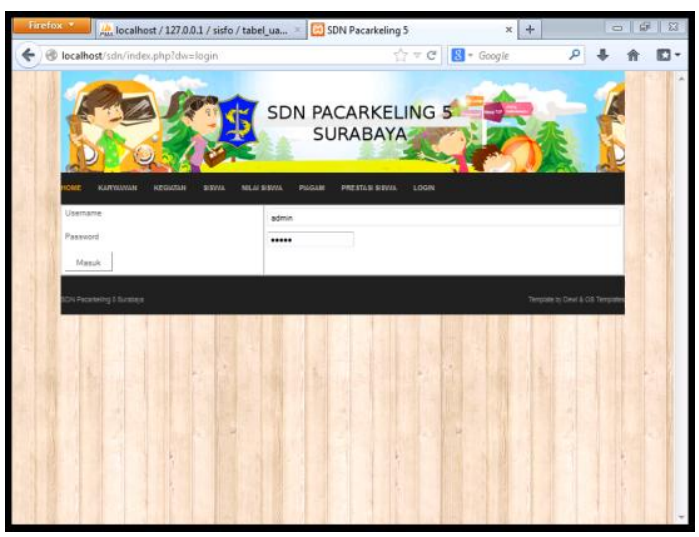

Gambar 21. Pengisisan text box admin 


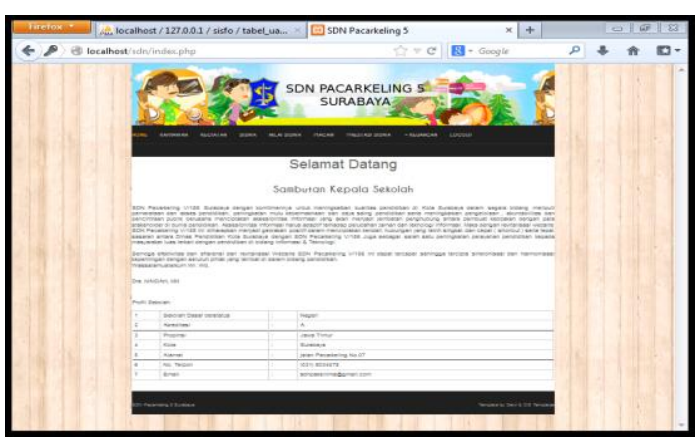

Gambar 22. Halaman awal admin

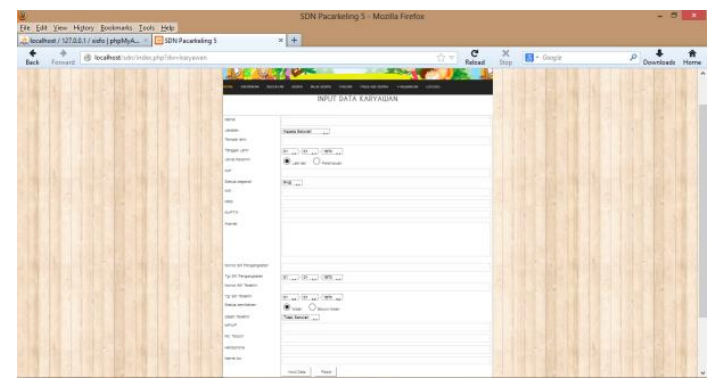

Gambar 23. Form karyawan

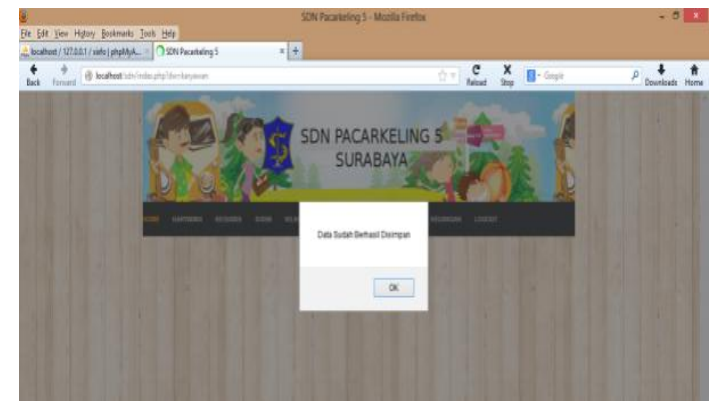

Gambar 24. Halaman data karyawan yang telah berhasil ditambahkan

Pada halaman admin 'karyawan' akan di perlihatkan form pengisian data karyawan dan untuk melihat data karyawan yang telah tersimpan logout dahulu dan masuk ke data 'karyawan'.

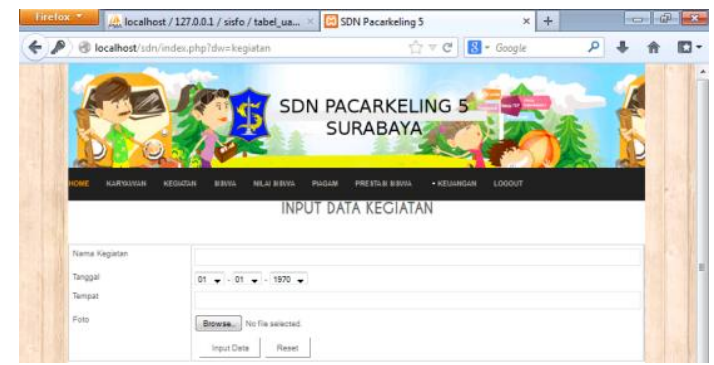

Gambar 25. Halaman form kegiatan

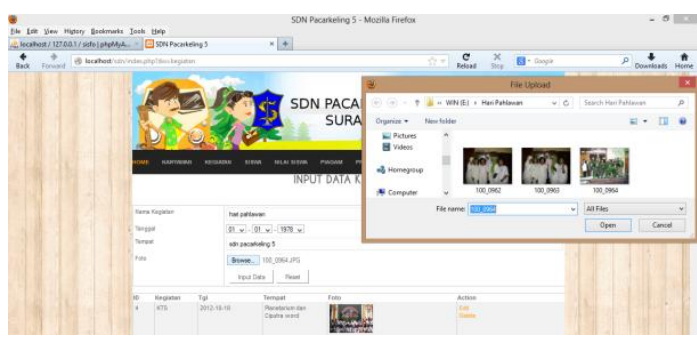

Gambar 26. Halaman pengisian form kegiatan

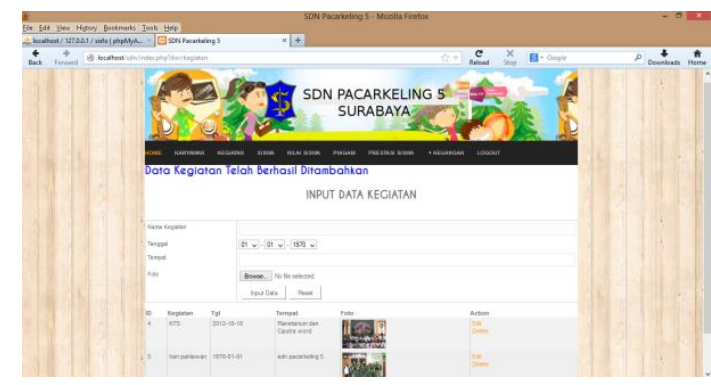

Gambar 27. Halaman data kegiatan yang telah berhasil ditambahkan

Pada halaman kegiatan akan di perlihatkan cara pengisian form pengisian, form pengisian data kegiatan dan data kegiatan yang telah tersimpan.

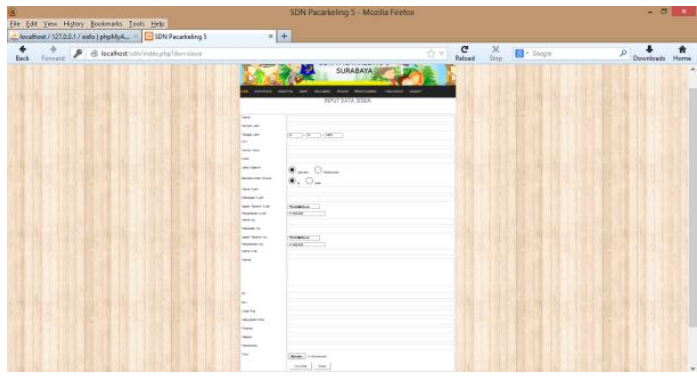

Gambar 28. Halaman form siswa

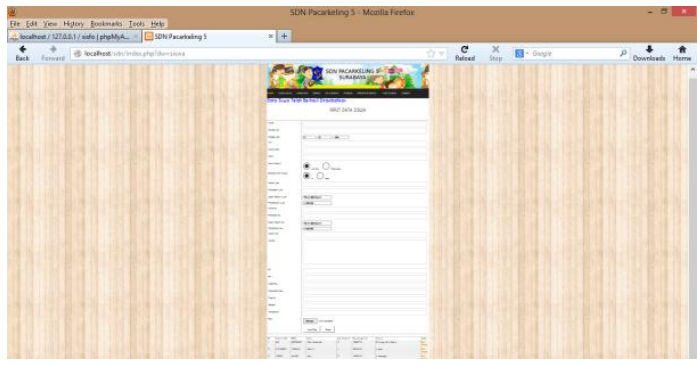


Gambar 29. Halaman data siswa bila berhasil ditambahkan

Pada halaman siswa akan diperlihatkan form pengisian data siswa dan data data siswa yang telah tersimpan.

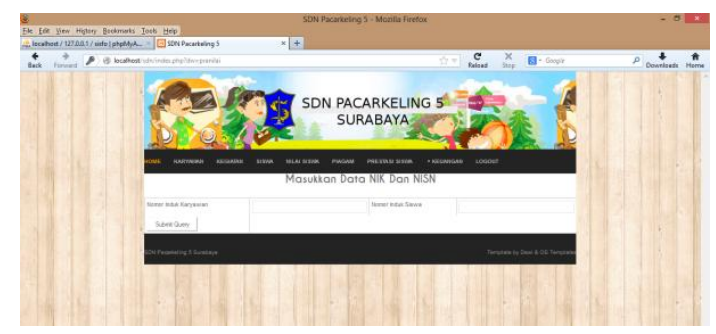

Gambar 30. Halaman login nilai siswa

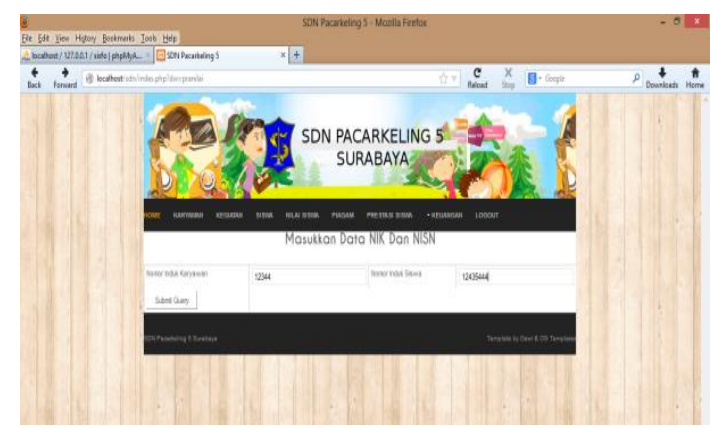

Gambar 31. Halaman pengisian login nilai siswa

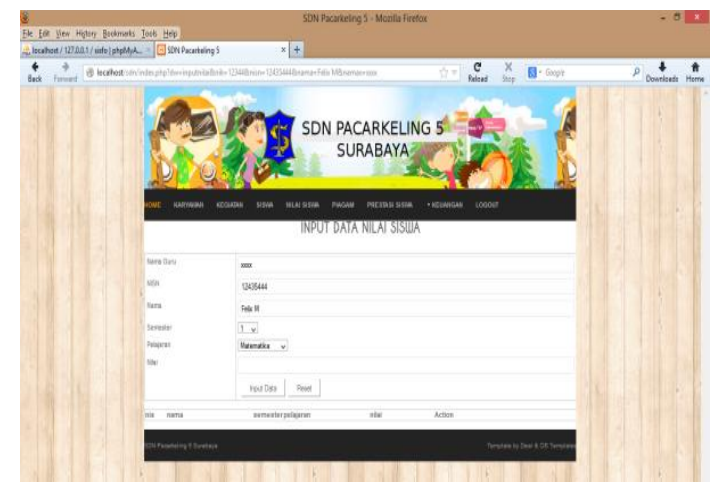

Gambar 32. Halaman form nilai siswa

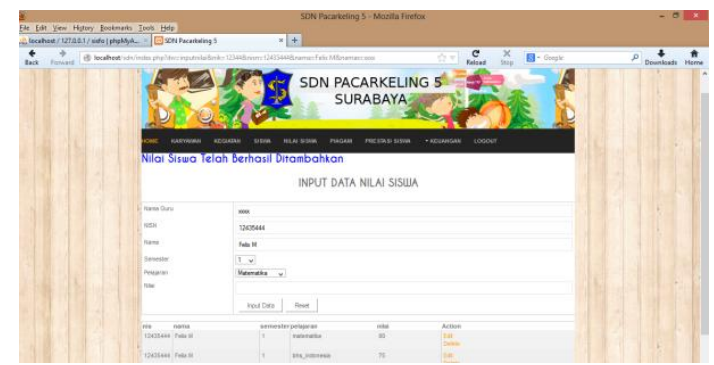

Gambar 33. Halaman data nilai siswa bila berhasil ditambahkan

Pada halaman nilai siswa akan di perlihatkan halaman login, form pengisian nilai siswa, cara pengisian dan nilai siswa yang telah tersimpan.

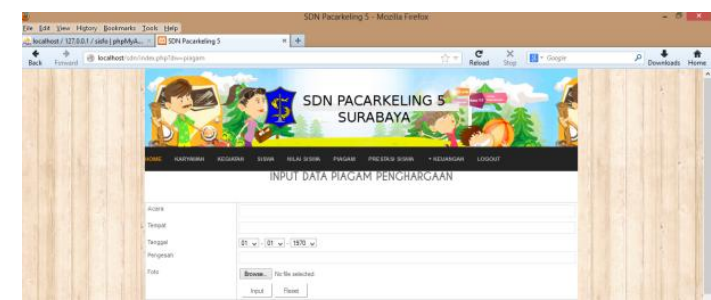

Gambar 34. Halaman form piagam

Pada halaman piagam akan di perlihatkan form pengisian data piagam cara pengisian form data piagam dan data piagam yang telah tersimpan.

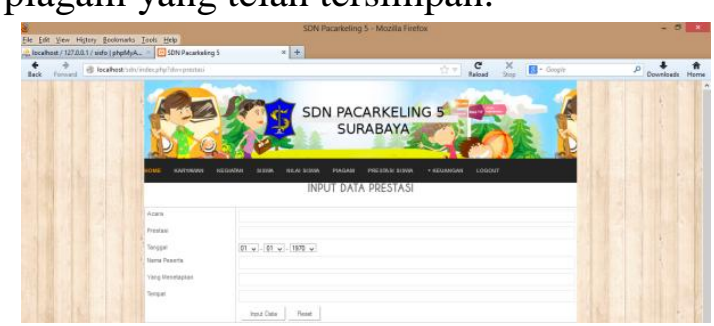

Gambar 35. Halaman form prestasi siswa

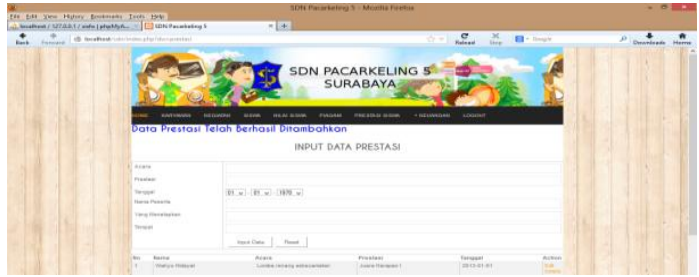

Gambar 36. Halaman prestasi siswa yang berhasil disimpan

Pada halaman prestasi siswa akan diperlihatkan form pengisian data prestasi siwa dan data prestasi siswa yang telah tersimpan. 


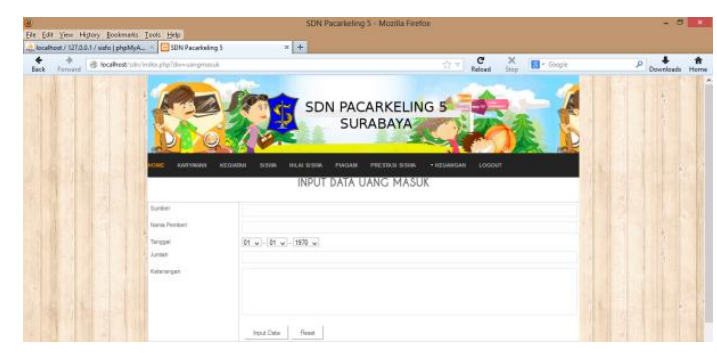

Gambar 37. Halaman form uang masuk

Pada halaman uang masuk akan di perlihatkan form pengisian data uang masuk dan data uang masuk yang telah tersimpan.

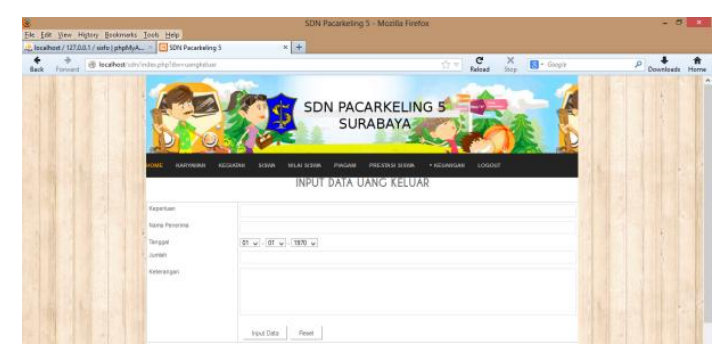

Gambar 38. Halaman form uang keluar

Pada halaman uang keluar akan di perlihatkan form pengisian data uang keluar dan data uang keluar yang telah tersimpan.

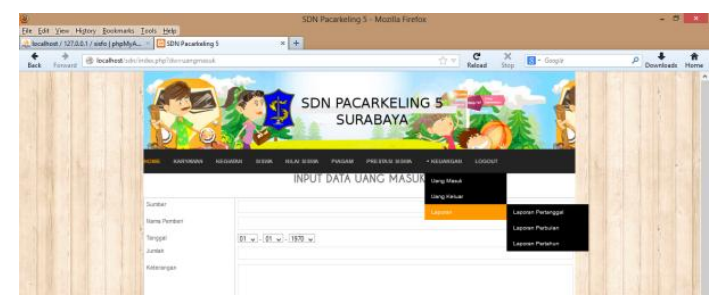

Gambar 39. Halaman masuk ke laporan keuangan

Pada laporan keuangan terbagi 3 halaman, yaitu :

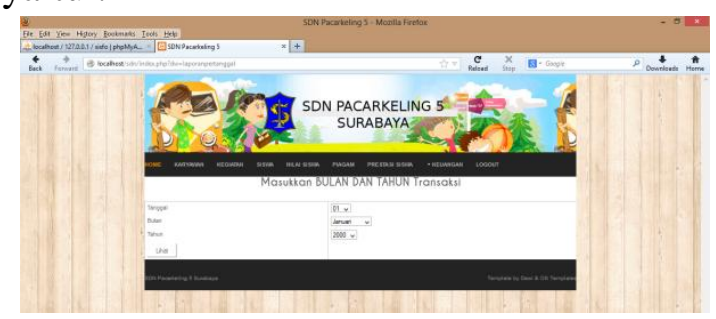

Gambar 40. Halaman laporan uang pertanggal

Pada halaman login laporan keuangan pertanggal akan diperlihatkan laporan keuangan pertanggal.

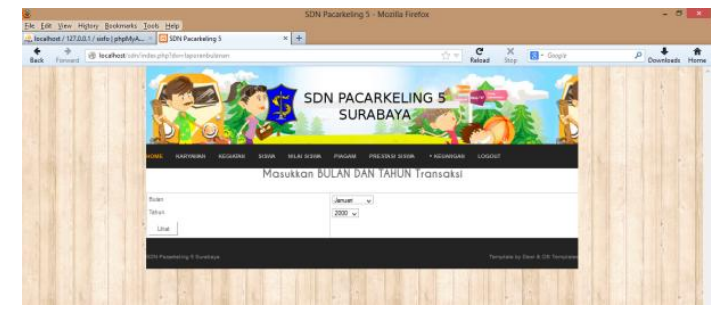

Gambar 41. Halaman masuk ke laporan keuangan perbulan

Pada halaman login laporan keuangan perbulan akan diperlihatkan laporan keuangan perbulan.

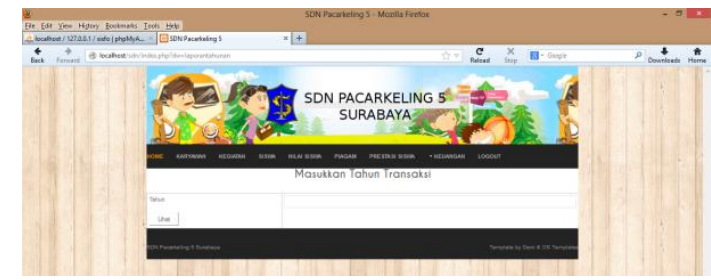

Gambar 42. Halaman masuk ke laporan keuangan pertahun

Pada halaman login laporan keuangan pertahun akan diperlihatkan laporan keuangan pertahun.

\section{KESIMPULAN DAN SARAN}

Setelah menyelesaikan perancangan Sistem Informasi Sekolah Terpadu di SDN Pacarkeling $\mathrm{V}$ berbasis web ini, penulis menarik beberapa kesimpulan sebagai berikut:

1. Sistem informasi sekolah terpadu di SDN Pacarkeling V berbasis web ini memudahkan admin untuk pendataan siswa. 
2. Sistem informasi sekolah terpadu di SDN Pacarkeling V berbasis web ini ini mempermudah sekolah untuk menyampaikan informasi-informasi tentang sekolah kepada orang tua dan masyarakat

3. Sistem informasi sekolah terpadu di SDN Pacarkeling V berbasis web ini ini mempermudah orang tua untuk mengetahui perkembangan putraputrinya

Beberapa saran untuk pengembangan dan perbaikan pada Tugas Akhir ini, antara lain:

1. Sistem keamanan pada program ini masih sangat jauh dari sempurna, oleh karena itu kedepannya penulis berharap sistem ini di kembangkan dan disempurnakan lagi guna mendapatkan sistem keamanan yang lebih baik lagi.

2. Untuk pengembangan selanjutmya diharapkan sistem informasinya tidak hanya terpaku pada beberapa bagian informasi sekolah saja, sebaiknya informasi sekolah yang disajikan lebih lengkap dan luas.

\section{DAFTAR PUSTAKA}

Roki Aditama, 2012, Sistem Informasi Akademik Kampus Berbasis Web denganPHP, Loko Media, Yogyakarta.

Ansari Saleh Ahmar, 2004, Panduan Sistem Informasi Akademik Sekolah Berbasis Web,Loko Media, Yogyakarta.

Andrean Adelheid \& Khairil Nst, 2012, Buku Pintar menguasai PHP MySql, Media Kita, Jakaeta Selatan.
Sandi Hariadi,2010, Trik dan Solusi Jitu Pemrograman Web, Loko Media, Yogyakarta.

Roki Aditama, 2012, Pemrograman Database dengan Mysql, Andi, Yogyakarta.

Alan Nur Aditya, 2011, Jago PHP \& Mysql, Dunia Komputer, Jakarta. 